\title{
Creating Affinity
}

\author{
Formal Friendship and Matrimonial Alliances \\ Among the Jê People and the Apinaje Case
}

\author{
Prof. Dr. Odair Giraldin \\ Federal University of Tocantins - UFT
}

\section{Resumo}

Neste artigo apresenta-se uma discussão sobre a relação entre a amizade formal e um sistema matrimonial entre os Apinaje. Inicia com uma discussão sobre a amizade formal entre os povos Jê, apresentando semelhanças e diferenças existentes entre os vários povos daquela família lingüística. Em seguida, após expor as descrições da amizade formal apinaje realizadas por Nimuendajú e DaMatta, propõe-se um modelo da transmissão da amizade formal entre os Apinaje. Finalmente, procura-se mostrar que a relação de amizade formal recria um sistema virtual de metades e argumenta, com base em dados etnográficos, que a amizade formal é utilizada como um elemento afinizador, sobrepondo-se, em alguns casos, à consangüinidade.

Palavras chave: amizade formal; Apinajé; etnologia sul-americana; Jê

\begin{abstract}
This article analyzes the link between formal friendship and a matrimonial system among the Apinaje people. Starting with an analysis of formal friendship among the Jê, it presents existing similarities and differences among various peoples in the same linguistic family. Then, after describing the Apinaje's formal friendship formed by Nimuendajú and DaMatta, a formal friendship transmission model among the Apinaje is proposed. Finally, the paper shows that formal friendship recreates a virtual system of moieties, and based on ethnographic data argues that formal friendship is used for creating affinity in social relationships, overlapping, in some cases, consanguinity.
\end{abstract}

Keywords: Formal Friendship; Apinaje; South American ethnology; Jê people 


\title{
Creating Affinity
}

\author{
Formal Friendship and Matrimonial Alliances \\ Among the Jê People and the Apinaje Case
}

\author{
Prof. Dr. Odair Giraldin \\ Federal University of Tocantins - UFT
}

\section{Introduction}

When ethnographic data about the Jê people became available in the 1930's and 40's through Nimuendajú's writings (for ex. 1939; 1946), the kinship terminology enabled their classification into the Crow and Omaha system. In Lévi-Strauss' studies, especially in the classic Elementary Structures of Kinship (1949-1982), peoples with a Crow-Omaha system were classified as semi-complex societies, with non-elementary kinship structures.

It is important to remember that in societies with elementary structures, matrimonial alliances are defined by the "relationship method" (Viveiros de Castro, 1993:152), through the levels of kinship between partners (marriage between cross cousins), enabling an exchange of wives between two groups (restricted exchange, also enabling exchanges of brothers), or through the "class method" (Idem), in a series of exchanging groups, respectively donors and receivers of wives (general exchange).

It must be said that in these types of societies, the allied group inherits the alliance. In societies with non-elementary kinship structures, marriage is not defined by exchanges among groups but rather according to interests between persons or units that form alliances based on parameters that are not related to kinship, and are not alliances that can be inherited.

In a subsequent study, Lévi-Strauss himself revised this position, showing that even in complex societies there are alliances that are formed among moral persons, such as royal families, for example, in a type he called "House societies" (sociétés à maison) (Lévi-Strauss [1984] 1991).

Héritier (1989) followed the same path in her studies about semi-complex societies, demonstrating how in semi-complex societies it is possible to use an "elementary" base with a system of sibling exchanges (Héritier, 1989:47). 
Marriage arrangements among the Apinaje ${ }^{1}$, according to Nimuendajú, occur through matrimonial exchanges among four exogamic groups, the four Kiyê (which I prefer to spell hikjề). This information made the Apinaje an anomaly among the Jê people of Central Brazil and throughout the world.

But, in addition to marriage among the four hilkjê, Nimuendajú also indicated that the Apinaje also had a marriage prohibition between parallel and cross cousins, people who among themselves would be in a "piwkwa" position (MZD and FBD) for an Ego male and in a "kamy" position (MZS and MBS) for an Ego female (Nimuendajú, [1939] 1983:58).

When DaMatta analyses the data about the four hiljjê of Nimuendajú, he affirms that in the entire genealogy of that society, an indicative standard of regular exchanges between the groups defined as hikjê cannot be found. For DaMatta, the genealogic data show that the Apinaje are a "typically bilateral group in which marriages have nothing to do with preferences" (DaMatta, 1976a:137). DaMatta reports that when asked whether it would be good to marry with wives from the other moieties or not, interviewees emphatically affirmed "No! We always choose the wives!" (DaMatta, 1976a:137).

Since the Jê people have Crow-Omaha systems and can thus be classified as non-elementary, according to Lévi-Strauss ([1949] 1982), because they have no rules concerning marriage between cross-cousins, this presupposition could have influenced DaMatta's interpretation of the Apinaje case, leading him to affirm that "there are no ideologies nor statistic facts indicating a prescriptive matrimonial system" (DaMatta, 1976a:137). ${ }^{2}$

However, as early as 1960, Maybury-Lewis drew attention to a possible matrimonial system among Apinaje people different from the one described by Nimuendajú. For Maybury-Lewis (1960:199), marriages among the Apinaje were not regulated by the four-group system described by Nimuendajú (the so called four kiyê), nor determined by the descent system. Analyzing the data provided by Nimuendajú, Maybury-Lewis argued that there were both statistical and structural reasons indicating that the Apinaje did not have a matrimonial system based on the four hikjê.

1 I use the spelling of Apinajé with "j" and not "y", as they are traditionally known in the literature, according to how they themselves write their ethnonym.

2 Perhaps this is also why Manuela Carneiro da Cunha said that formal friendship has no relation with marriage (Carneiro da Cunha, 1978:77). She, however, noted that there were cases of fathers-in-law and sons-in-laws or mothers-in-law and daughters-in-law who were formal friends. 
Since the alliance is not formed through the four hilkjê, Maybury-Lewis hypothesizes that there would be, among the Apinaje, a system of alliances based on two sections, but in this case they coincide with two moities. He presents many indicators that point to a system of exogamic moiety alliances. The first one is that the Apinaje are a Timbira Group, speaking a Jê language and with a moieties system, which characterizes the other Jêspeaking groups. Since there are exogamic moieties described for other Jê groups (Maybury-Lewis cites the Eastern Timbira, the Xerente and the Kaingang, in addition to exogamic Xavante and Bororo clans and exogamic moities). Because there are exogamic moieties described in other Jê groups, he postulates that the Apinaje may also have this system (Maybury-Lewis, 1960:201). A second indicator can be verified in the kinship terminology, characteristic of a two-moiety system. Comparing the Apinaje terminology with other Timbira terminology, Maybury-Lewis argues that the differences between them are variations in the same Crow-Type terminological structure (Maybury-Lewis, 1960:210).

Another indication made by Maybury-Lewis that the Apinaje have an alliance system between exogamous moieties, is the correlation between the system and the transmission of hikjê formal friendship. The Ego male's formal friends, according to Nimuendajú's description, would be a male of the same hilkjê and a female of the Ego's mother's hilkjê. Maybury-Lewis also indicates that in Apinaje myth, the Sun and Moon are formal friends and embody the moieties Koti and Kore who are, conceptually, formal friends. MayburyLewis thus affirms that the relations among Apinaje's formal friends link people belonging to complementary moieties. So, as in many societies, the ceremonial obligations between moieties also correspond to obligations of reciprocal marriage, Maybury-Lewis concludes that the Apinaje marriage system is regulated not by hikjê but by an exogamic moieties system, which he believed to be matrilinear. ${ }^{3}$

DaMatta followed the Maybury-Lewis's hypothesis when considering the four hilkjê as residuals of the Apinaje kinship system. His work has shown that the four ceremonial groups presented by Nimuendajú are limited to two groups that form the pair of Hipôknhõxwỳnh and Ixkrénhõxwỳnh moieties.

3 He says: "We have therefore grounds for supposing that marriage among the Apinayé was regulated by a system of matrilineal exogamous moieties" (Maybury-Lewis, 1960:212). 
Apart from this misunderstanding by Nimuendajú, DaMatta also verified that the krã-ô-mbedy and krékára, which were considered to be two exogamic groups by the German ethnologist, were in fact the names of specific decorations, respectively, of Hipôknhõxwỳnh and Ixkrénhõxwỳnh moieties presented by a formal friend.

Even though he has followed Maybury-Lewis' hypothesis when considering the system of four hikjê as residual, DaMatta did not do the same with the hypothesis of a possible Apinaje matrimonial system between exogamic moieties. On the contrary, DaMatta argued that the two pairs of moieties found among the Apinaje, play no role in the definition of a possible matrimonial system (DaMatta, 1976a:103).

Since the 1990's, the anthropologist (“jêologist”) Vanessa R. Lea (1995) has been presenting the thesis that formal friendship among Jê people plays the role of an "otherness paradigm," as she correctly maintained (Lea 1999), inspired by Manuela Carneiro da Cunha's affirmation that the essence of formal friendship is being the Other (Carneiro da Cunha, 1978:84).

Without falling into the "byzantine" (Viveiros de Castro, 1995:9) and controversial theoretical debate on prescription versus preference, I would like to present some information that demonstrates that Lea's hypothesis (1995) about the relation between formal friendship and an alliance system among the Mbengôkré (Kayapó), is also applicable to the Apinaje case.

\section{The mode of transmission and relationship among Apinaje formal friends}

Lopes da Silva (1986:191) affirms that there are two variables to the transmission rule of formal friendship among the northern Jê people: one by nomination, the other by patrilineage. The Eastern Timbira are inserted in the first case, according to Lopes da Silva, with formal friendship being a relationship formed through the use of personal names. The users of certain names have, as well, a group of formal friends. This group is inherited by the new users of the names when they are transmitted. This variable that we could accept as a classical model of the northern Jê, can be clearly applied to the Krahô and Krĩkati case. However, among the Pyhcopkatiji (Gavião) and the Ràmkôkamẽkra-Canela, the transmission of formal friendship is indirectly connected to nomination. One of the ways to establish formal friendship is 
through nominator relations. Another way is during ritual moments, such as river baths when one is in reclusion. ${ }^{4}$

\section{Diagram 1}

Suya's formal friendship terminology (from Seeger, 1981)

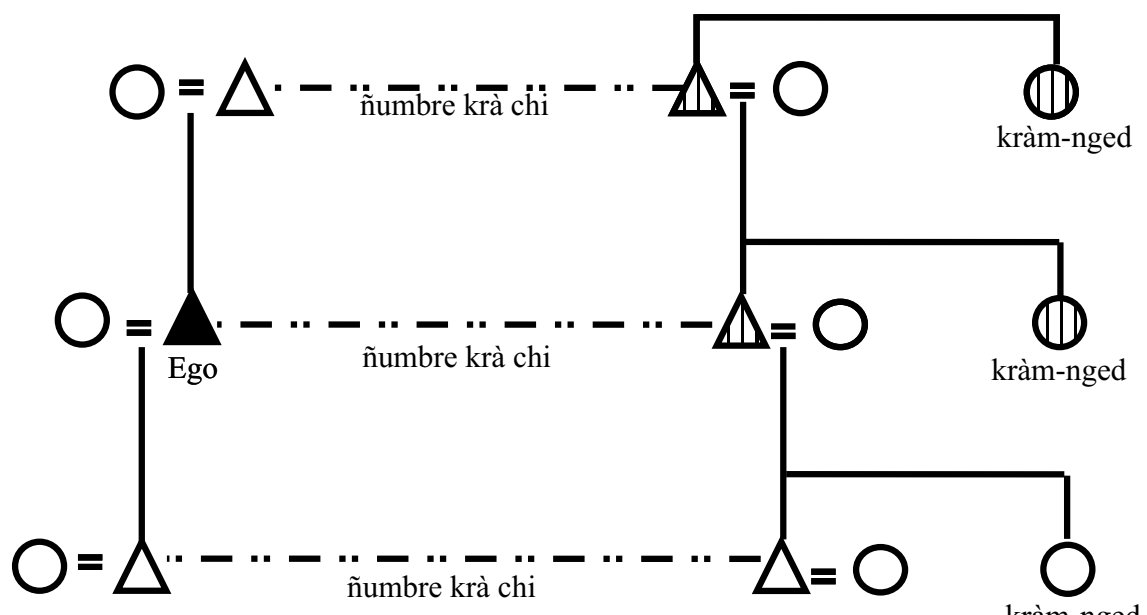

consanguineous relationshhip (parents and childs)

formal friends relationship

Note: All the hachured positions (hachure insert by me in Seeger's diagram) are Ego's formal friends.

Among Mẽbêngôkre (Kayapó), formal friends are inherited in a patrilinear way as fathers and sons share the same formal friends (Lea 1995).

Among the Suyá, Seeger's data (1981), even if it is not conclusive, indicates formal friendship only between male partners. It is, in fact, an inherited friendship since the sons and daughters of a man's formal friend will be formal friends of the man's sons and daughters. The Ego male will have as formal friends the formal friend of his father, the sisters of this man, and his sons and daughters (Seeger, 1981:142-143). The term used by Ego and his

4 This subject, however, requires more study because the ethnographic data is not sufficient to provide a clear view of this theme for Ràmkôkamekra, Apãnyekra and Pyhcopcatiji. 
formal male friends is auto-reciprocal: ñumbre krá chi (see diagram 1). On the other hand, between Ego and his formal female friend, the reciprocal terms are kràm gêd and ñumbre krá chi. As we will see below, this model joins the Suyá case to the Apinaje system, because in both a group of formal friends is transmitted.

Formal friendship among the Apinaje is similar to that among other northern Jê people concerning its functions and role and the mystical character of the kràmgêx / pahkràm relationship, which can involve solidarity and avoidance relationships. However, the form of transmission of formal friendship has its own characteristics. It is connected to the nomination system, but not to names. This specificity of the form of transmission also leads to particular sociologic results. ${ }^{5}$

The Apinaje nomination system involves three to four people. There is the person that receives the name (the named), the person that arranges the name (the name arranger ${ }^{6}$ ); the person that in fact transmits the name (I'll call him the nominator) and the person who has the transmitted name (the eponym). Usually, the nominator is also the eponym, since he is the person who must be the gêt (MB, MF, FF and all the men from the second ascendant generation) or tyj (FZ, FM, MM and all the women from the second ascendant generation) of the named. However, it is possible that the eponym had already died or was away during the nomination ceremony. In this case, the name arranger looks for someone who has the same group of names, to confirm the same ones. If there is no other namesake, it is possible to ask someone who knows the list of names of the group to make the confirmation. In these two cases of eponym substitution, the name arranger has to reward the substitute for the "service."

A child receives, either immediately at birth or sometime after birth (ranging from a few days to a few months), a group of names that is given to him by a name arranger, 7 and that needs to be confirmed in a ceremony. This

5 Thus, my interpretation partially confirms the Maybury-Lewis' insight (1960:212) that there would be a connection between formal friendship and a marriage system between exogamic moieties, as I have argued earlier (Giraldin, 2000:xi-xiii).

6 The term "names arranger" does not really apply to the role of this person. The fact of arranging names for someone also implies that the arranger will have social responsibilities towards the nominee for both of their entire lives. However, I use this term because it is already established in Apinaje literature.

7 A child can have more than one person "arranging" names for it. The "quantity" of name arrangers depends on the initiative of brothers and sisters (consanguineous or classificatory) of its consanguineous parents. 
name arranger usually announces one of the names from a certain group that he wants to transmit to the named. During the nomination ceremony, the nominator (who must also be the eponym) will announce which names from the group he will transmit to the named, thus confirming them. This name arranger is always a person who is in his pãm (FB), nã (MZ), gêt (MB, FF, $M F)$, or tyj (FZ, FM, MM) category. Even though the name arranger could belong to the nã, pãm, gêt or tyj categories (consanguineous or classificatory) of the person who is going to receive the name, there is a predominance of $\mathrm{MZ}$ (ña) and FB (pãm), as name arrangers. The nominator and eponym must be someone who is in the gêt or tyj category of the person who receives the name. The named person will always be someone who is in the tãmxwỳ category (SCh, DCh, ZCh, BChCh...) in relation to the nominator and the eponym.

\section{Nimuendajú's and DaMatta's data about Apinaje Formal Friendship}

To understand how formal friendship expresses this otherness language and how this Apinaje matrimonial system is organized, it is necessary to understand the transmission. To do so we will first see how the transmission of formal friendship was presented by Nimuendajú and DaMatta. For Nimuendajú, the transmission of formal friendship occurred through the initiative of a child's father or grandfather. When a child reaches the age of five, the parents or grandparents can choose ${ }^{8}$ one man and one woman who seem to be kind (Nimuendajú doesn't explain the choice), to enter into a relation of kràmgêx/ pahkràm with the child. Nimuendajú reports, however, that the invitation of the parents or grandparents is made by asking two people to make decorations to be given to their kra pyràk (named children).

When presenting the transmission rule of formal friendship, DaMatta, in a text published in 1976, says that the child's lkràmgêx ${ }^{9}$ :

Is always, (...), a pá-krã of one of its pam or nã-kaog, in such a way that the boy or girl winds up belonging to the same ceremonial group as its father and

8 Nimuendajú ([1939] 1983) doesn't explain if there was a preference for one of them.

9 DaMatta used three terms to refer to Apinaje's formal friendship: for formal male friends, he wrote krã-geti and pá-krã; for female formal friends, he used krã-gedy and pá-krã. In the following pages, I only use two terms: kràmgêx and pahkràm. 
ceremonial or adoptive mother, the one who - on the other hand - passed the marks of its ceremonial moieties to an adoptive son or daughter of one of he krã-geti (DaMatta, 1976: 160).

In The Divided World, the rule that DaMatta express for the transmission of formal friendship is different form the one presented before. ${ }^{10}$ Based on Diagram 2 (below), he says that, "the krã-geti of the male child will be the krã-geti's son of his adoptive father. And in the feminine case, the krã-gedy will be the krã-gedy's daughter, her adoptive mother" (DaMatta, 1976a: 139 emphasis mine).

As we can see, there is a difference between the two statements. In the first one (from the 1976 text), an Ego will have as pahkràm a kràmgêx of one of his pãm or nã-kaàk. In the second (1976a), a male Ego will have as kràmgêx a son of the kràmgêx of the adoptive father (or name arranger). On the other hand, a female Ego will have as kràmgêx the kràmgêx's daughter of her adoptive mother (or name arranger). DaMatta, however, doesn't specify if this kràmgêx's son or kràmgêx's daughter, are consanguine or classificatory. We will see further on that this difference between consanguine and classificatory children has important sociologic significations.

Diagram 2

Apinaje formal friendship transmission

by DaMatta (1976a: 140)

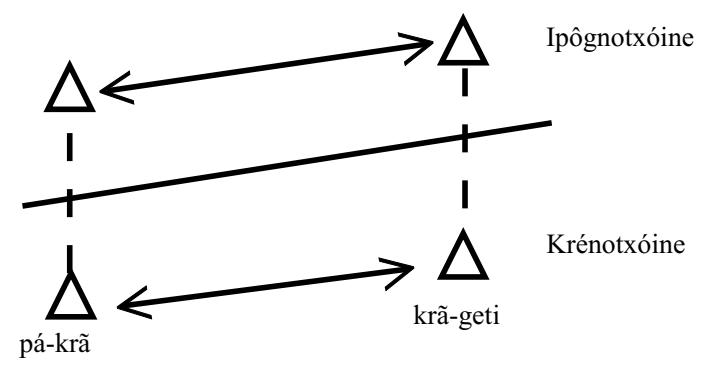

The broked lines presents relations among named and name arranger.

The double pointed line show formal friendship relations.

10 These problems with ethnographic data linked to the transmission of formal friendship were also shown by Lea (1995). 


\section{Diagram 3}

Apinaje formal friendship transmission

by DaMatta (1979:111)

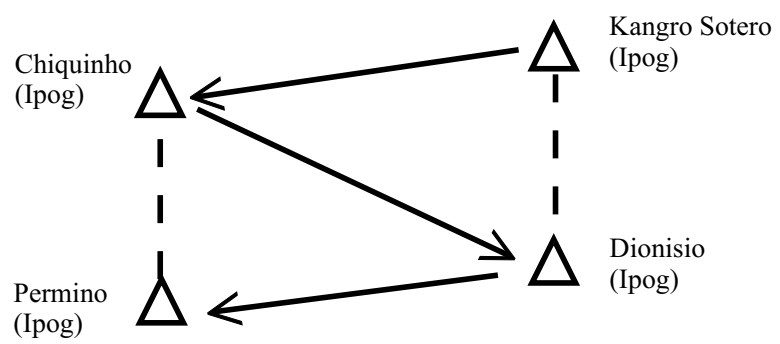

The broked lines presents relations among named and name arranger.

The line with arrow point to formal friendship relations.

In a later text DaMatta (1979), makes the same affirmation as he did in the article published in 1976 , and not that made in The Divided World. ${ }^{11}$ To support his argument, he presented a diagram (diagram 3 above) that was quite different from the one presented earlier. In it, it is noticeable that there are moiety exchanges in a way that Ego would have his name arranger's formal friend as his own formal friend (a pahkràm), to whom (the pahkràm) the name's arranger would have handed over the decorations.

In any case, his argument is that formal friendship establishes two continuing lines of formal friendship in the system of a member's inclusion in one of the Apinaje moieties pair. ${ }^{12}$ Therefore, DaMatta did not convincingly clarify how the kràmgêx is chosen. After all, according to DaMatta, an Ego can have more than one kràmgêx, and each one could even be from any one of the moieties. In addition, a male Ego can have formal female friends, but DaMatta doesn't provide any information about how these choices can be

11 Trindade-Serra complicates even more the question. "The chosen senior friend, or krã-geti (reciprocal = pá-krã), will always have to be the subjects adoptive father's krã-geti (in the case of a female Ego, the krãgedy will be the krã-gedy's daughter of his adoptive mother)" (Trindade-Serra, 1978:230 [my emphasis]). Trindade-Serra presents different rules for male and female Egos. For the first, the kràmgêx would be the same as his adoptive father. For a female Ego, it would be the daughter of kràmgêx of his adoptive mother.

12 The moieties that he names as Krenotxuine (in my writing: Ixkrénhõxwỳnh) and Ipôgnotxuine (Hipôknhõxwỳnh). The filiation to the other Apinaje's moieties' pair, (Koti / Kore) is established through onomastics. 
made and which terms would be used in this case. ${ }^{13}$

While Nimuendajú says that the choice was made by sympathy, DaMatta says that the rule for formal friendship transmission is that a female Ego would have a formal friend (kràmgêx) who is a daughter of her name arranger's formal friend, while a male Ego would have as a formal friend (kràmgêx) a son of his name arranger's formal friend. This way, there would be male and female transmission lines, which would have misled Nimuendajú to interpret an affiliation according to exogamic groups (hilkjê) and the existence of a parallel transmission.

From information that I gathered, formal friendship is not transmitted by providing decorations, as DaMatta affirms, and is not used for affiliation to a second pair of moieties. Formal friendship is established by the name arranger independently from handing over the decorations. The handing over of the decorations as argued elsewhere (Giraldin, 2000: 187), is a ritualization of the creation myth, when Mỳyti and Mỳwrỳre acted in the transformation of the world. This ritual is also used to establish a matrimonial alliance, through an ideal (and primordial) matrimonial alliance between the moieties Koti and Kore. This primordial alliance leads the current Apinaje, especially the elders, to have an ideology of ideal marriage between members of the two moieties. As we will see further on, this ideology is followed with statistical data about marriages between consanguineous children of formal friends.

A name arranger has many groups of formal friends. Each of his groups of formal friends is composed of a senior formal friend and a group of senior formal friends, and a group of junior formal friends. These junior formal friends of Ego's name arranger are the people who are in the position of named children (classificatory) of the name arranger's senior formal friend. Senior and junior formal friends are named kràmgêx (reciprocal, pahkràm).

Thus, Ego's formal friends (kràmgêx) (male or female) will all be the formal friends (and their named children) of their name arrangers. I use the plural because this is how it happens. Even if Ego has only one name arranger, he will have a group of people who will be his formal friends (kràmgêx). This group will be composed by all the people who will be in a position of named children (kra pyràk) in relation to the senior kràmgêx or junior lkràmgêx, ${ }^{14}$

13 A problem raised by Lea (1995).

14 This distinction between senior and junior formal friends is not made by the Apinaje. I make it to 

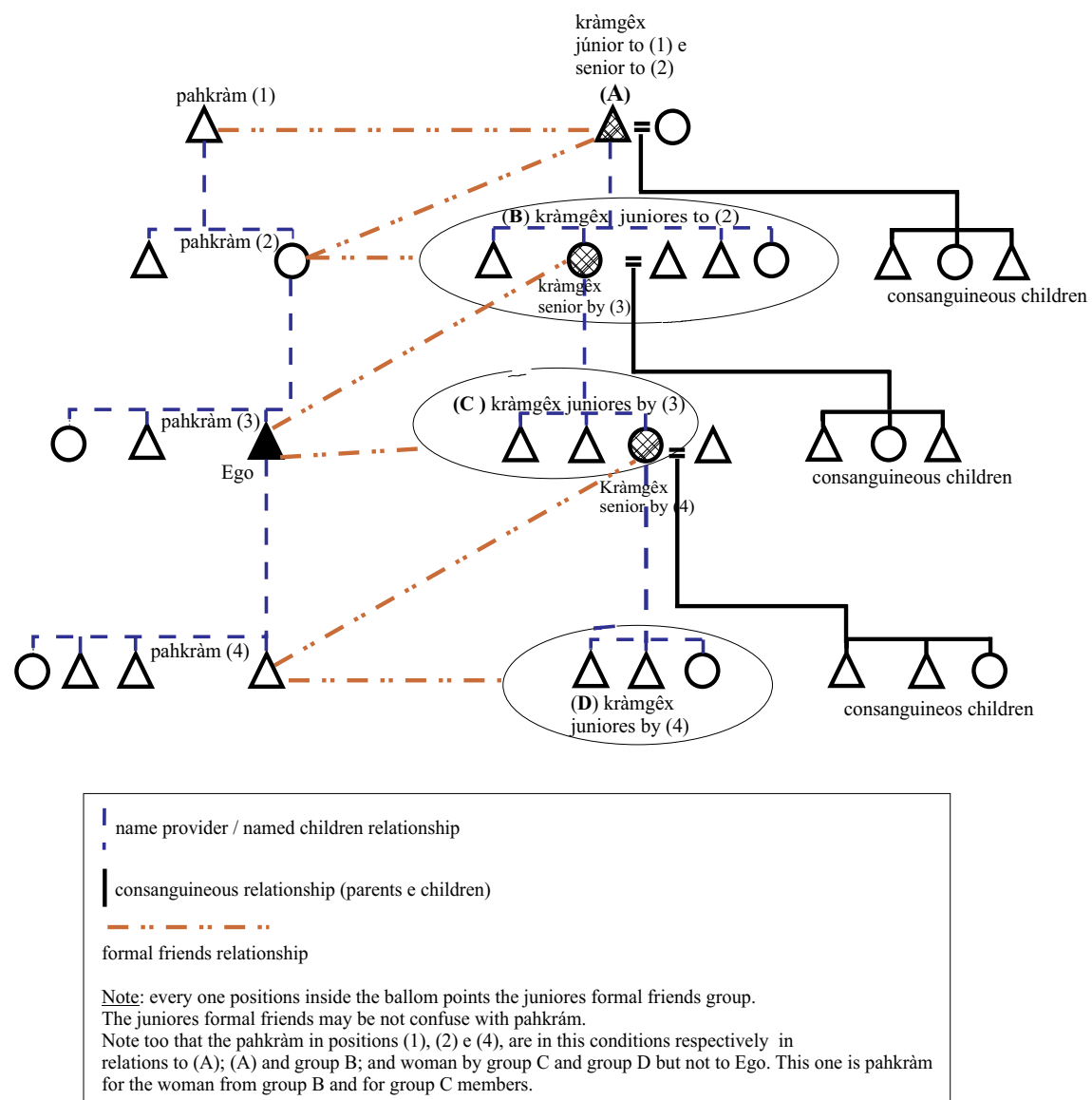

Diagram 4, presented below, aims to facilitate the understanding of the transmission process of formal friendship and its implications in a matrimonial system. The kràmgêx $(\mathbf{A})$ who appears at the top of the diagram (hatched) is a junior formal friend for pahkràm (1) and is a senior formal friend for pahkràm (2). On the other hand, his named children (group of people $(\mathbf{B})$, for whom the kràmgêx $(\mathbf{A})$ arranged the names, are junior formal friends (junior kràmgêx) of (2). When the man pahkràm (1) asks his junior formal friend (A) to hand over the decorations to his named daughter (2) (in other words, for whom (1) arranged names), (A) will be accompanied by all of his named children (B). These will become junior formal friends of the 
woman (2). When the woman (2) needs the services of a formal friend for one of her named children (such as for digging graves, transferring the deceased to the cemetery; giving the baths on the seventh day after burial or handing over decorations) she will call on one of her junior formal friends (B). This formal friend, in return, will perform the requested task or ask one of his named children (C) to do it.

During the handing over of decorations to (3), this junior formal friend (hatched area of group B) of pahkràm (2) woman becomes a senior formal friend of the man pahkràm (3), at the same time as her named children (C) becomes his junior formal friend. Finally, pahkràm (3) will have the persons who belong to group $(\mathbf{C})$ as formal friends, those who will become the junior formal friends, and a member of the group of persons of (B), who will be the senior formal friend. When the man (pahkràm (3)) will have a named son (4) (for whom her (3) arranged names), he will call one of his junior kràmgêx (C) to become kràmgêx of his kra pyràk (named son). The transmission cycle is thus infinite.

An important point that needs to be highlighted is that the calculation used to establish formal friendship happens between persons that are connected through the nomination system and not by consanguineous bonds. Another point that needs highlighting is that the consanguineous children don't take part in the transmission of formal friendship together with their parents. This absence of consanguineous children in the transmission of formal friendship is related, according to my interpretation, to the ideal matrimonial system created with that relation, as we will see further on.

\section{The Apinaje's formal friendship in the basis of marriage calculation}

As I said previously, there is an ideology as well as statistical data that indicate a matrimonial system through preferential partners. We can speak of a system of alliance among Apinaje people as being ideally socio-centered, but empirically realized in an ego-centered way. This characteristic gives this system a prescriptive form as well as a performative one. I am inspired by the concepts of Sahlins' prescriptive and performative structures. He says that in a social form of prescriptive structure social actions (and relations) are defined by pre-existing relations. In a social form of performative structure, the 
actions create the adequate social relations, as in the exchange of presents (a social action) to create social relations (friendship) (Sahlins [1985]1990:12; 47).

The alliance among Apinaje, to my understanding, has features that aim at a "prescriptive structure" as well as at a "performative structure." In a certain sense, it has "prescriptive elements", since there is the preexistence of a relation between groups (the moieties Koti and Kore). But, this relation needs to be constantly updated, since it occurs through the decorations presentation ritual by the formal friend. This way, the performative actions of the agents are those that create the adequate social relation between formal friends in this process of updating the primordial alliance among Mỳyti (Sun) and Mỳwrỳre (Moon)'s children. This allows the consanguineous children as well as the nominated ones to have ideal partners for a matrimonial relationship. The alliance established in this way between two people occurs for two generations, that were previously considered to be needing renewal. There are renewals for new generations that are established through the transmission of formal friends. ${ }^{15}$

The Apinaje social philosophy, based on a principle of hierarchical dualism, indicates that marriage should ideally occur among Koti and Kore, as defined by Mỳyti and Mỳwrỳre. But, since the moieties Koti and Kore don't form groups that perform as such, the alliance between them is thus symbolized through the formal friendship relation.

This relation doesn't even form groups, since the formal friendship doesn't create descendant groups. The alliances are thus ego-centered. So each person revives the ideally socio-centered alliance through new social relations of formal friendship. According to individual interests, a man or a woman can thus use their formal friendship to widen their relationships through matrimonial arrangements made with their children.

In a conversation with Katàm Kaàk- Amnhimy (Grossinho), one of DaMatta's principal informers, he discussed marriage and formal friendship. Grossinho told me that DaMatta had studied the issue and he mentioned an experience the anthropologist had when he called a girl iprõ-ti and how she became scared and began to cry. According to DaMatta, this term, "far from indicating a symptomatic terminology of matrimonial prescription (as I

15 There are indications of a possible extension of the alliances for three generations (reaching formal friends' grandchildren). 
initially thought), is used to mark a separation of these positions (DaMatta, 1976a:141). For him, the term iprõ-ti, applied to the girl signified that a man is going to use violence against her.

Grossinho's information shows that in fact kràmgêx cannot marry pahkràm. But it is possible to have a marriage between kràmgêx and pahkràm's consanguineous children. The reciprocal is also true, pahkràm can marry kràmgêx's consanguineous children.

In Diagram 4 of the formal friendship transmission model (presented above), it is possible to verify that consanguineous children didn't take part in the transmission of their parents' formal friendships. In other words, when handing over the decorations or realizing ceremonial activities, the senior kràmgêx is accompanied only by his named children (kra pyràk). This way, formal friendship transforms senior kràmgêx's named children into pahkràm's junior kràmgêx, prohibiting sexual intercourse among them since they are formal friends. However, formal friendship makes this possible between kràmgêx (senior and junior) and pahkràm's consanguineous children, and between consanguineous children of all formal friends (whether they are senior or junior kràmgêx) and pahkràm's consanguineous children.

For this reason, I affirmed that this type of alliance happens not between groups, but between two persons, presenting marriage possibilities for two generations: for the senior kràmgêx's consanguineous children, for junior kràmgêx (who are the named children of senior kràmgêx), for junior kràmgêx's consanguineous children, and finally, for pahkràm's consanguineous children. This is also why it is necessary to be always establishing new formal friendship. This ideology is found among Apinaje, who affirm that it is necessary to be always renewing, expanding, and moving preexistent relations forward. Because it's a relation between only two generations, it is necessary to renew them periodically.

A marriage can be decided by individual initiative where the partners choose freely his or her spouse (as mentioned by DaMatta [1976a:137]). When there are arrangements, they are made through the actions of the name arranger (male or female). In this case, the main basis for the calculation of the arrangements is formal friendship.

We can see in Diagrams 5 (A-F) presented above that in some cases the terms of affinity are better understood when they are connected to the 
Diagram 5

Apinaje's affinity terminology

and formal friends relationship

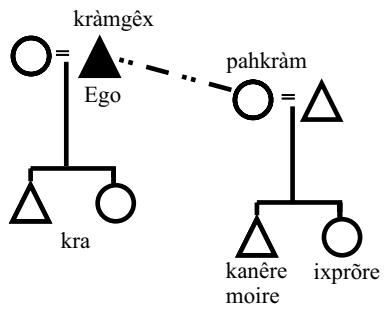

Diagram 5 A

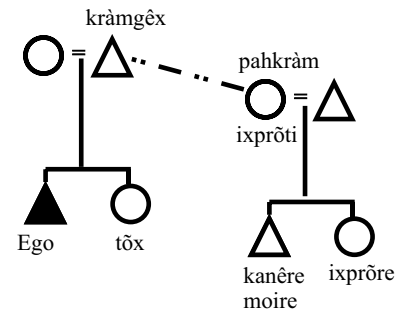

Diagram 5 C

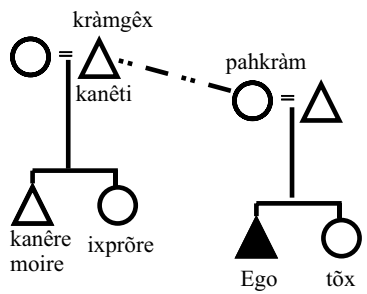

Diagram 5 E

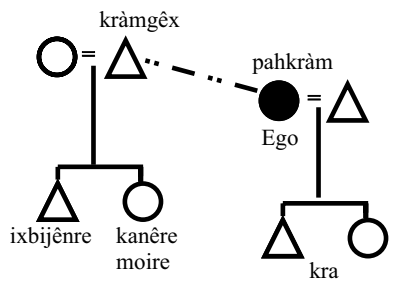

Diagram 5 B

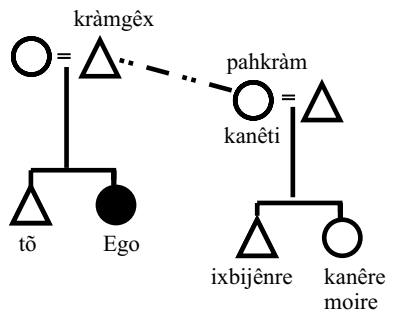

Diagram 5 D

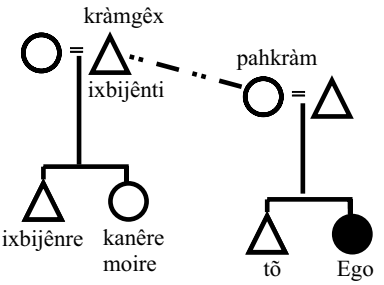

Diagram $5 \mathrm{~F}$ $\overline{\text { consanguineous relations (parents and children) }}$ $-\cdot \cdot-\cdot \cdot-\cdot$

formal friends relationship
Gloss

kràmgêx $=$ formal friend (reciprocal $=$ pahkràm) ixprõ $=\operatorname{my}[\mathrm{ix}]$ wife [prõ $]$

( $\mathrm{ti}=$ augmentative; $\mathrm{re}=$ diminutive $)$

ixbijên $=$ my[ix] husband [bjiên]

(ti $=$ augmentative; re $=$ diminutive $)$

kanê $=$ synonym to father-in-law and brother-in-law

moire $=$ synonym for brother-in-law $(\mathrm{moi}=$ thing $)$

tõ $=$ brother

tõx $=$ sister

$\mathrm{kra}=$ children 
terminology adopted for formal friendship. This relation also helps understand that there is an ideal exchange between moieties ${ }^{16}$ Koti and Kore.

In Diagrams $5 \mathrm{~A}$ and $5 \mathrm{C}$, we see that a man refers to the consanguineous children of his formal friend (kràmgêx or pahkràm) with the same terms used for his own consanguineous son. The same is true of the woman (according to diagram $5 \mathrm{~B}$ and $5 \mathrm{~F}$ ) who refers to the consanguineous children of her formal friend (kràmgêx or pahkràm) with the same terms she uses for her consanguineous daughter.

This terminology used between kràmgêx and pahkràm's consanguineous children (or vice-versa) can change according to gender. When they are the same gender, the kràmgêx will call kanêre ${ }^{17}$ or moire ${ }^{18}$ his pahkràm's consanguineous son, as can be seen in diagram $5 \mathrm{~A}$.

The pahkràm's consanguineous son will call kanêti his father or mother's kràmgêx, as can be seen in diagram $5 \mathrm{E}$. The same occurs between two females. Since they are the same gender, the term used is always one related to avoidance. But, when there is a difference in gender, the terminology changes.

The kràmgêx will call his pahkràm's consanguineous daughter with the term ixprõre (literally "little wife"), as seen in diagram $5 \mathrm{~A}$, and he will be called ixbjênti by her (literally "big husband"), as seen in diagram $5 \mathrm{~F}$. The terminology between kràmgêx's consanguineous sons and pahkràm's consanguineous sons is also very interesting. Kràmgêx and pahkràm's

16 According to Nimuendajú, there are, among the Canela, two moieties, kq'ikateyê (east) and harã kateyê (west) that are (or were) exogamic. These moieties, according to him, are not associated to sun and moon, and do not have any distinctive characteristic. These moieties only have an exogamic role. According to him, "although a third of contemporary marriages are in the same moieties" [while two-thirds follow the rule, which is the significant majority] " and the youngest generation partly refuses the reality of the exogamic rule, elders depreciate this shameless attitude and the preponderance of exogamic unions among them proves that the principle survived until not too long ago" (Nimuendajú,1946:79). For Nimuendajú, the comparison with the organization of other tribes suggests that the functions now given for the patio moieties and rainy seasons were initially associated with exogamic moieties.

17 The term kanê is used to refer to a specific element that is used as a counter-element. To fight a disease, the Apinaje use a medication that is a counter-element to the one that provokes the disease. So, for the armadillo's disease, they use the armadillo-kanê. This is a plant that looks like the armadillo. When someone casts a spell in the village, threatening the people (the panhĩ), those in charge of eliminating it (known as killing the spell) are the killers (panhĩ-kanê). So, kanê can be considered as an alterity manifestation, of the opposite. Nhĩnôpo and Nhĩnôkàre, two Apinaje characters connected to the legend of an ancestral village called each other kanê-re because their mothers were formal friends.

18 The term moire ( $\mathbf{m o i}$ = thing), is also used to refer to a brother-in-law (WB ou HB). 
consanguineous sons call each other, kanêré or moiré, as seen in diagrams ${ }_{5} \mathrm{C}, 5 \mathrm{D}, 5 \mathrm{E}, 5 \mathrm{~F}$. But when there is a difference in gender, the terminology changes. A man will call ixprõre the consanguineous daughter of his father or mother's kràmgêx or pahkràm and will be called ixbjênre by her, as seen in diagrams 5 C, 5 E. The same applies for a female Ego. A woman will call ixbjênre the consanguineous son of her father's or mother's kràmgêx or pahkràm and will be called ixprõre by him, as shown in diagrams $5 \mathrm{D}, 5 \mathrm{~F}$.

To summarize: the diagrams and terminologies presented show equivalences between a man and his consanguineous son, since both call the father's pahkràm's consanguineous son kanêré; and are called by him with the same term: kanêti (for the kràmgêx) and kanêre (for the kràmgêx's consanguineous son). The same terminology is used by a man and his consanguineous son when referring to the father's pahkràm's consanguineous daughter. Both call this woman ixprõre. The reciprocal is also true: both are called ixbjên (ti, for kràmgêx; and re, for his son) by the woman. There is also equivalence between a woman and her consanguineous daughter, as both call the mother's pahkràm's (or kràmgêx) consanguineous daughter kanêre and are called kanê (re or ti) by her. In the same way, they call the mother's pahkràm's or kràmgêx's consanguineous son ibjênre and are called respectively ixprõti and ixprõre by him.

The following diagrams show some examples that clarify the relation between marriage and formal friendship. It is not an exhaustive demonstration of all concrete matrimonial consummation, but presents some cases that demonstrate that formal friendship is an element that influences matrimonial arrangements.

Among marriages between the family of the couple Amnhimy-Katàm Kaàk's (Grossinho) and Pãxti (Rosa) ${ }^{19}$, who lived in the village of Patizal (in 1997), for $85 \%$ of them we notice a relation of formal friendship among the parents of the spouses. Some examples can be seen in the diagrams.

In diagram 6 there is a case of a brother's exchange, as Moxy (Juraci),

19 Only in the cases of the marriages of Amnhimy (Grossinho) and Pãxti (Rosa), as well as in the one of Irepxi (Tete [Amnhimy \{Grossinho\} and Pãxti \{Rosa]\}'s consanguineous daughter) and Kagàpxi (Marabá) and the one of Gurôt (Araci [Amnhimy \{Grossinho\} and Pãxti \{Rosa\}'s consanguineous daughter) and Rõrkỳ (Roberto [Gôtum [Camilo]'s consanguineous' son) it was not possible to detect any relation of formal friendship. 
Meôkà (Pedro) and Pp krãkaĩ (Juvenal), three Amnhimy (Grossinho) and Pãxti (Rosa)'s consaguineous children, respectively married, Teprãre (Jorge), Grerti (Celina), and Apamy, three consanguineous children of Tepjêt (Vicente) and Grerô (Eva). Tepjêt (Vicente) is Amnhimy (Grossinho)'s pahkràm. So that, kràmgêx's children married with pahkràm's.

\section{Diagram 6}

Formal friends and marriage relations between

Tepjêt and Amnhimy children

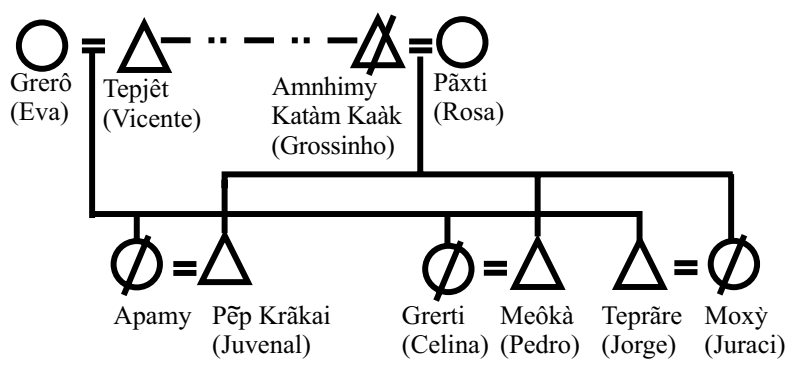

consanguineous relationship (parents e children)

formal friends relationship

dead

In diagram 7 we can see that two children of the couple Amnhimy (Grossinho) and Pãxti (Rosa) also married two of Tepjêt (Vicente)'s grandchildren, which demonstrates that the alliance between two people can be extended to a third generation. Amnhimy (Grossinho) and Pãxti (Rosa)'s consanguineous children, Ire (Rosita) and Kamêr Kaàk (Paulo), married children of Kangro (Chico) and Amnhi (Edna) who is Tepjêt and Grerô's consanguineous daughter.

In São Jose, the largest village in Apinaje territory, with an estimated population of 700 (September 1999), I researched one hundred and eight marriages. I verified that in 71 cases there is a relation of formal friendship between one of the spouses and one of the parents-in-law. The result is that $68 \%$ of the marriages are or have been in an ideal condition. 


\section{Diagram 7}

Formal friends and marriage relations between

Tepjêt grandchildren and Amnhimy children

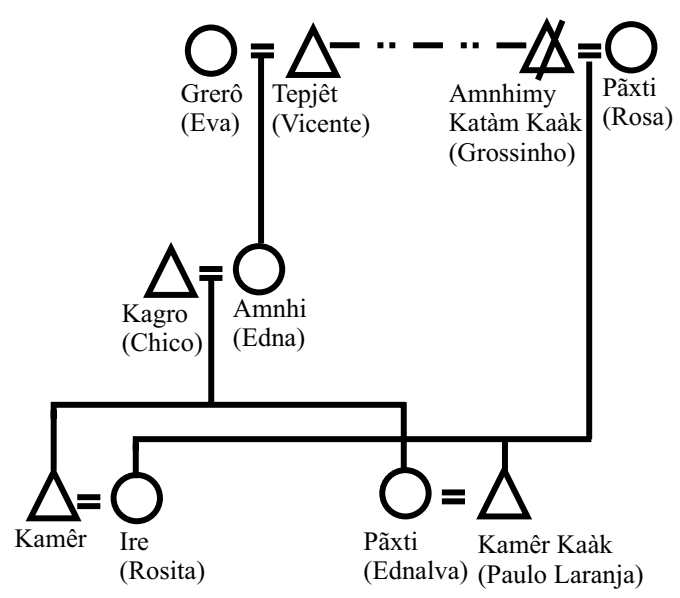

$$
\begin{aligned}
& \text { consanguineous relationship (parents e children) } \\
& \text { formal friends relationship } \\
& /_{\text {dead }}
\end{aligned}
$$

In diagram 8, we can see the marriages of Irepxi's and Krãkamrêk's children. This couple had seven children; five of them are represented in this diagram. All of them are or have been married to partners with whom their mother (Irepxi) or father (Krãkamrêk) have relations of formal friendship.

Information about this marriage can be seen from left to right. Sikoi is married to Krãkamrêk (Valdemar), Tepjêt (Vicente) and Grerô (Eva)'s consanguineous son. Eva was the pahkràm of Krãkamrêk (Augusto), Sikoi's father. So, this is a case where the children of formal friends got married. Kunuka (Abdão), Irepxi's consanguineous son married Jàt kamrêk (Marlene), Nhĩnôkênh (Joãozinho)'s consanguineous daughter. Nhĩnôkênh (Joãozinho) was Irepxi's kràmgêx. Children of formal friends again got married. The case of the marriages between Kamêr kamrô (Maria Santana), Amnhàk (Rosalina) and Krãkamrêk (Joaquim), Irepxi's consanguineous children and respectively Grekrw (Jairo), Pãnpãn and Ireti (Darci), all cosanguineous children of Môxgô (Moisés) (Irepxi's kràmgêx) and Grermàn (Veneranda), is another case 
of sibling exchange. It is true that from the three marriages, only Pãnpãn and Amnhàk's marriage prospered, since they raised two children before separating. But the formal friends, Irepxi and Môxgô, tried to marry their children properly and continued to avoid each other, since one doesn't go to the house of the other, except on special occasions (such as a funeral).

\section{Diagram 8}

Formal friends and marriage relations of

Irepxi (Maria Barbosa) and Krãkamrêk (Augusto) children

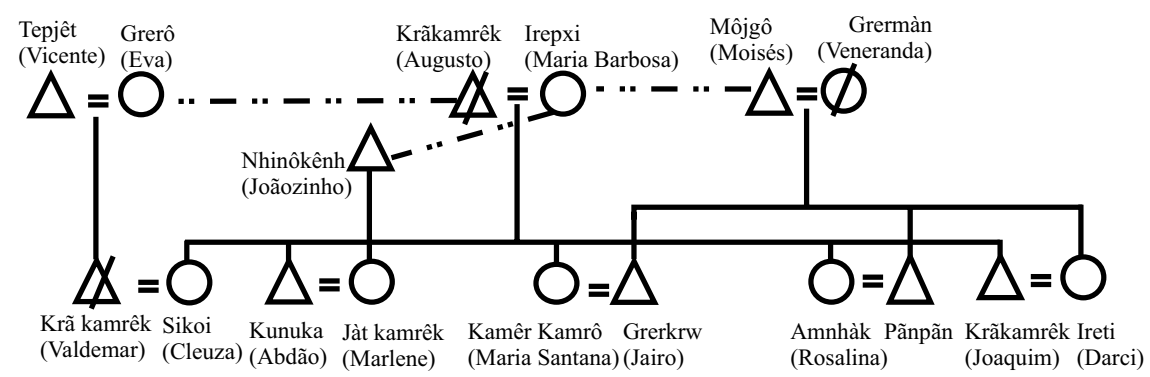

$$
\begin{aligned}
& \text { consanguineous relationship (parents e children) } \\
& \text { formal friends relationship } \\
& \gamma_{\text {dead }}
\end{aligned}
$$

\section{Conclusion}

In a paper about the role of affinity in indigenous societies of South-America lowerland, Viveiros de Castro argued that Jê formal friendship has a role of "potential affinity," since it is an example of "affinity without affines." This, according to the author "is limited in a relation that puts together terms just not connected to marriage" (1993:179). Among the Jê, formal friendship would be this situation of "affinity without affines," since there is no matrimonial connection between formal friends.

In fact, it is possible to agree with Viveiros de Castro's argument. The Apinaje's formal friends, among themselves, constitute the "alterity paradigm” (Lea, 1999), since they avoid each other, "potential affines”. However, they are the "carriers of sociality" because they create "permanent affinity." 
As I affirmed in this paper, the ideal marriage is when a formal friend marries a child of another formal friend or that formal friend's consanguineous children marry each other.

\section{Diagram 9 \\ Exemple of invention of affinity cross formal friends. Marriage of Sikoi e Krã kamrêk}

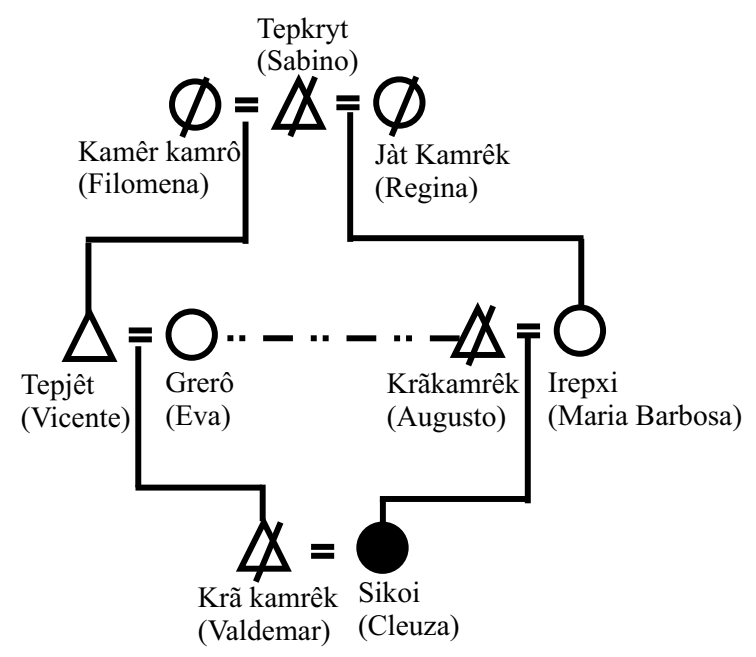

$$
\begin{aligned}
& \text { consanguineous relationship (parents e children) } \\
& \text { - .. - .. - . } \\
& \text { formal friends relationship } \\
& / \text { dead }
\end{aligned}
$$

It must be said once more that this "potential affinity" is explicit since the Apinaje's socio-genesis (and generally northern Jê) as we have seen, Mỳỳti (Sun) and Mỳwrỳre (Moon) were formal friends. In this condition, they were carriers of identity as well as alterity. When conceiving their children - respectively members of Koti and Kore's moieties - the condition of equality allows all Apinaje to see themselves as members of a community; the alterity condition (with "potential affines") enables the sociability through the conception of people under a condition of "effective affines" (formal friends' children). If Mỳyti (Sun) and Mỳwrỳre (Moon) were equals, their "children" would also have this condition, making impossible the formation of matrimonial relations. This way, we can agree with Lea (1999:11) that formal 
friendship permits the erasure of consanguinity traces between individuals, allowing an affinization. Diagram 9 for example, shows how two cross cousins (positions ideally prohibited inside the system they are called brother and sister) have been able to marry under the argument that the "parents in law" (WF and HM) had relations of formal friendship.

For these reasons, I disagree with Viveiros de Castro's affirmation that a dualist system (such as the Apinaje's) is of "little matrimonial significance." Similarly, we can notice that the Apinaje matrimonial system occurs under an ideology of exogamic moieties, without, however, having as "operative units," clans or lineage as are found in other Central Brazilian societies (like the Xerente, Xavante, Bororo) as Viveiros de Castro maintained (1995:12).

The Apinaje function with a dualist ideology of exogamic moieties, in a cognatic system without the existence of clans or lineage. This system operates empirically through the symbolic creation of these moieties through relations of formal friendship. This way, with ideal marriages between formal friends' consanguineous children, there is an ideal exchange of members between the two moieties.

\section{Bibliography}

CARNEIRO DA CUNHA, Manuela. 1978. Os mortos e os outros. Uma análise do sistema funerário e da noção de pessoa entre os índios Krahó. São Paulo: Hucitec.

DAMATTA, Roberto A. 1976. "Uma reconsideração da morfologia social Apinayé". In: E. Schaden(org.), Leituras de etnologia brasileira. São Paulo: Companhia Editora Nacional. pp. 149-163

DAMATTA, Roberto A. 1976a. Um mundo dividido. A estrutura social dos índios Apinayé. Petrópolis: Vozes.

DAMATTA, Roberto A. 1979. "The apinayé relationship system: terminology and ideology”. In: D. Maybury Lewis (ed.), Dialectical societies. The Gê and Bororo of Central Brazil. Cambridge, Massachusetts, Harvard University Press. pp 83-129

GIRALDIN, Odair. 2000. Axpên Pyràk. História, cosmologia, onomástica e amizade formal apinaje. Tese de doutorado, IFCH/Unicamp, Campinas. HÉRITIER, Françoise. 1989. "Parentesco". In: Enciclopédia Einaudi. Vol. 20, “Parentesco". Lisboa: Imprensa Nacional/Casa da Moeda. pp. 27-80 
LEA, Vanessa. 1995. "Casa-se do outro lado: um modelo simulado da aliança $M$ bengokre (Jê)". In: E. Viveiros de Castro (org.), Antropologia do parentesco. Estudos ameríndios. Rio de Janeiro: Editora da Universidade Federal do Rio de Janeiro. pp. 321-359.

LEA, Vanessa. 1999. "Os amigos formais $m$ bengokre: paradigma de alteridade e portadores de socialidade”. Paper destinado ao XXIII Encontro Anual da ANPOCS.

LÉVI-STRAUSS, Claude. 1982 [1949]. As estruturas elementares do parentesco. 2a ed. Petrópolis: Vozes.

LÉVI-STRAUSS, Claude. 1991 [1984] Minhas palavras. 2a ed. São Paulo: Brasiliense.

LOPES DA SILVA, Aracy. 1986. Nomes e amigos: da prática xavante a uma reflexão sobre os Jê. São Paulo: FFLCH/USP.

MAYBURY-LEWIS, David 1960. "Parallel descent and the apinayé anomaly". Southwestern Journal of Anthropology, 6(2):191-216

NIMUENDAJÚ, Curt. 1939. The Apinayé. Washington: The Catholic University of America Press.

NIMUENDAJÚ, Curt. 1946. The Eastern Timbira. Berkeley and Los Angeles. University of California Press.

NimuendAJú, Curt. 1983 [1939]. Os Apinayé. Belém: Museu Paraense Emílio Goeldi.

SAHLINS, Marshall. 1990 [1985]. Ilhas de história. Rio de Janeiro: Jorge Zahar Editor.

SEEGER, Anthony. 1981. Nature and society in Central Brazil. The Suyá indians of Mato Grosso. Cambridge, Massachusetts: Harvard University Press.

TRINDADE-SERRA, Ordep José. 1978. "Dualismo e harmonia: a propósito do caso Apinayé”. Anuário Antropológico, 77: 225-243.

VIVEIROS DE CASTRO, Eduardo. 1993. "Alguns aspectos do dravidianato amazônico”. In: E. Viveiros de Castro \& M. M. Carneiro da Cunha (orgs.), Amazônia: etnologia e história indígena. São Paulo: Núcleo de História Indígena e do Indigenismo da USP/ FAPESP. pp 149-210

VIVEIROS DE CASTRO, Eduardo. 1995. "Pensando o parentesco ameríndio". In: E. Viveiros de Castro (org.), Antropologia do parentesco. Estudos ameríndios. Rio de Janeiro: Editora da Universidade Federal do Rio de Janeiro. pp. 7-24. 


\section{About the author}

Odair Giraldin, (giraldin@uft.edu.br) master in Anthropology and doctor in Social Science at Unicamp, associate professor at Federal University at Tocantins. Published: Cayapó e Panará. Luta e Sobrevivência de um Povo Jê no Brasil Central. Campins, Ed. Unicamp, 1997 and A (Trans)Formação Histórica do Tocantins. $2^{\mathrm{a}}$. ed. Goiânia, Ed. UFG, 2004.

Address: Rua Aureliano de Azevedo, 2476-A. Praça das Mães. Porto Nacional TO. CEP 77500-ooo. Fones: (63) 33632675 - cel. (63) 9202-809o ou 84540785.

Received 14/04/11, approved 02/08/11 